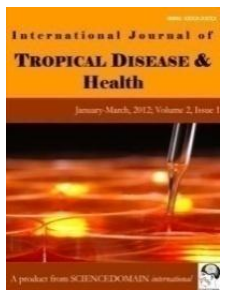

International Journal of TROPICAL DISEASE

\& Health

5(4): 252-259, 2015, Article no.IJTDH. 2015.028

ISSN: 2278-1005

SCIENCEDOMAIN international

www.sciencedomain.org

\title{
Economic Stress and the Secondary Sex Ratio: Ireland, Iceland, Greece and Latvia
}

\author{
Grech Victor $^{1 *}$ \\ ${ }^{1}$ Academic Department of Paediatrics, Mater Dei Hospital Medical School, Malta.
}

Author's contribution

The sole author designed, analyzed and interpreted and prepared the manuscript.

Article Information

DOI: $10.9734 / \mathrm{IJTDH} / 2015 / 13450$

Editor(s):

(1) Yingjun Yan, Department of Medicine, Vanderbilt University School of Medicine, USA.

Reviewers:

(1) Anonymous, IBN TOFAIL University, Kenitra, Morocco.

(2) Anonymous, University of Turku, Finland.

(3) Vinayak K. Nahar, Department of Health, Exercise Science \& Recreation Management, The University of Mississippi, USA

Complete Peer review History: http://www.sciencedomain.org/review-history.php?iid=850\&id=19\&aid=7308

Original Research Article

Received $18^{\text {th }}$ August 2014

Accepted $24^{\text {th }}$ November 2014

Published $15^{\text {th }}$ December 2014

\section{ABSTRACT}

Introduction: Male live births occur slightly in excess of female live births at a ratio of approximately 0.515 (male/total births). Stress has been shown to reduce $\mathrm{M} / \mathrm{F}$, including stress engendered by contracting economies. This study was carried out in order to ascertain whether the economic depression caused by the Eurozone recession at the end of the previous decade influenced M/F in the European countries most heavily affected, namely Iceland, Ireland, Greece and Latvia.

Methods: Annual data on male and female live births were obtained directly from the World Health Organisation except for Latvia which was obtained from Eurostat. Quarterly data for Ireland was obtained from the Irish Central Statistics Office.

Results: There were no significant changes in M/F except in Ireland which showed a sharp and highly significant dip in 2007 due to a fall in M/F in the last quarter only $(p<0.0001)$.

Discussion: Darwinian evolution should encourage species to adapt to changing circumstances by altering the odds of having a child of a specific gender. Parents without stress and in good condition should produce sons since these are theoretically capable of producing more offspring, and viceversa. The findings for Ireland support the contention that economic stress is also capable of depressing $\mathrm{M} / \mathrm{F}$.

*Corresponding author: Email: victor.e.grech@gov.mt; 
Keywords: Birth rate/trends; shock/epidemiology; sex ratio; economics; infant, newborn.

\section{INTRODUCTION}

\subsection{The Male: Female Ratio at Birth}

Male births occur slightly in excess of female births and the ratio of live births is generally expressed as the ratio of male live births divided by total live births. Although this would be more accurately abbreviated as $\mathrm{M} / \mathrm{T}$ (male births divided by total births), it is widely (albeit technically incorrectly) abbreviated as $M / F$, and this will be used throughout. M/F is expected to approximate 0.515 , with $3 \%$ more males born than females [1]. The reasons for this discrepancy are multifactorial, and the relevant influences are legion [1,2].

In utero, the male fetus is more susceptible to morbidity and mortality from external influences than the female fetus, as well as being at higher risk for all obstetric complications [3]. Factors that typically reduce $M / F$ due to spontaneous termination of pregnancy (with male losses outnumbering female losses) include toxins and stress [4]. Such changes may be very abrupt and transient, as evidenced following the reunification of Germany when M/F fell sharply only for the year following reunification in the East German part, with rapid recovery [4].

\subsection{Economic Downturns}

Before the Great Depression in the 1930s, economists regarded the capitalist economic updown cycle as an inevitable consequence of this financial system. Since then, recession and (even more so) depression have been feared [5].

A country's economic growth is measured by changes in goods produced and services provided with time. It is conventionally cited as the annual percentage rate of increase/decrease in real gross domestic product (GDP), which is adjusted for inflation.

In economics, recession is defined as a business cycle contraction with a slowdown in economic activity that produces negative GDP values for at least two consecutive quarters. A depression is a sustained and severe recession that is accompanied by an increase in unemployment levels, a decrease in the availability of credit and of all economic activities in general, with large numbers of ensuing bankruptcies [5].
The Eurozone crisis was triggered by a global economic recession. Several European countries were heavily affected, with economic recession leading to outright depression [5]. These were Iceland, [6] Ireland, [7] Greece, [8] and Latvia [9].

It has been proposed that $M / F$ could serve as a surrogate health indicator, [10] or as an indicator of contracting economies in that secular trends in $\mathrm{M} / \mathrm{F}$ that demonstrate a decline in the expected excess of male births may indicate adverse population condition/s. This has been shown for the former East Germany after reunification in 1991, when the region's economy collapsed, accompanied by a sharp drop in M/F [4].

This study was carried out in order to ascertain whether M/F was affected by economic circumstances in Iceland, Ireland, Greece and Latvia. The null hypothesis was that $M / F$ remained unaffected by the financial downturn.

\section{MATERIALS AND METHODS}

Annual data on male and female live births were obtained directly from the World Health Organisation (Health for All (HFA) database) for Iceland, Greece and Ireland. Latvian data was obtained from the World Health Organisation Statistical Information System (WHOSIS). Data was available back to 1950 except for Latvia for which data was only available as far back as 1980.

For Ireland, quarterly data was downloaded from the website of the Irish Central Statistics Office, from the database section Births and Deaths Registered by Sex, Statistical Indicator and Quarter (/Stat Bank/Births Deaths and Marriages/VSQ01).

Annual GDP data for each country was downloaded as an Excel sheet from the website of the World Bank. The following years were identified as just prior to depression years and depression years respectively for each of the countries in this paper: Iceland: 2004-2008, 2009-2010; Ireland: 2004-2006, 2007-2010; Greece: 2004-2007, 2008-2012; Latvia: 20052007, 2008-2010.

Contingency tables were analysed for annual male and female live births using chi squared and chi squared for trend. These were performed 
using the Bio-Med-Stat Excel add-in for contingency tables [11].

Since $M / F$ is known to undergo secular variation, [12] only adjacent years were compared. This is particularly important as $\mathrm{M} / \mathrm{F}$ changes in response to economic stress have been shown to be rapid and transitory [4].

95\% confidence intervals for ratios by obtained using the quadratic equations of Fleiss equations [13]. $P<0.05$ was taken as significant.

\section{RESULTS}

5-year M/F data are shown in Fig. 1, and broad secular trends are evident. There is an overall decreasing trend in $\mathrm{M} / \mathrm{F}$ in Iceland and Greece as noted in earlier publications [14]. For Ireland, M/F peaks in the 1990s then gradual falls [14].

There were no significant changes in $M / F$ when this was compared with the periods before and during depression years for all four countries studied (Fig. 2 and Table 1).

Ireland exhibited a sharp dip in M/F in 2007 to well below the values in the previous and following years at 0.5074 (95\% 0.5037-0.5000 Table 2). This dip was highly significant when compared with the previous (chi=17.2, $p<0.001)$ and with the following years $(\mathrm{chi}=15.7, p<0.001)$.

Inspection of quarterly data for Ireland showed that this dip was caused by a sharp fall in M/F in the final quarter of 2007 to values well below any in the entire dataset at $0.4875(95 \% \mathrm{Cl} 0.4801$ 0.4950 - Fig. 3, Table 3). This dip was highly significant when compared with the previous (chi=18.1, p<0.001) and with the following quarters (chi=27.0, $p<0.001$ ).

\section{DISCUSSION}

The Trivers-Willard hypothesis suggests that Darwinian evolution should encourage species to adapt to changing circumstances by altering the odds of having a child of a specific gender. Parents in good condition who find themselves in a time of plenty should tend to produce sons as these have higher reproductive potential than daughters. Conversely, parents in poor condition during times of scarcity would be better off having daughters than sons as daughters are likelier to survive to reproductive age and do not have to compete to the levels that males face for mating rights [15].
Table 1. M/F, GDP\% and chi tests for periods before and during depression years for Iceland, Ireland, Greece and Latvia

\begin{tabular}{|c|c|c|c|}
\hline Iceland & 2004-2008 & \multicolumn{2}{|c|}{ 2009-2010 } \\
\hline $\mathrm{M}$ & 11446 & 5084 & chi \\
\hline $\mathrm{F}$ & 10878 & 4850 & 0.02 \\
\hline $\mathrm{T}$ & 22324 & 9934 & \\
\hline $\mathrm{UCl}$ & 0.5193 & 0.5217 & 0.88 \\
\hline $\mathrm{M} / \mathrm{F}$ & 0.5127 & 0.5118 & \\
\hline $\mathrm{LCl}$ & 0.5061 & 0.5019 & \\
\hline Mean GDP\% & 5.4 & -5.3 & \\
\hline Ireland & 2004-2006 & \multicolumn{2}{|c|}{ 2007-2010 } \\
\hline M & 131865.8 & 115670 & chi \\
\hline $\mathrm{F}$ & 125738 & 110123 & 0.09 \\
\hline $\mathrm{T}$ & 257603.8 & 225793 & $\mathrm{p}$ \\
\hline $\mathrm{UCl}$ & 0.5138 & 0.5143 & 0.77 \\
\hline $\mathrm{M} / \mathrm{F}$ & 0.5119 & 0.5123 & \\
\hline $\mathrm{LCl}$ & 0.5100 & 0.5102 & \\
\hline Mean GDP\% & 5.2 & -3.2 & \\
\hline Greece & 2004-2007 & \multicolumn{2}{|c|}{ 2008-2012 } \\
\hline M & 225842 & 287441 & chi \\
\hline $\mathrm{F}$ & 211326 & 270359 & 1.63 \\
\hline $\mathrm{T}$ & 437168 & 557800 & $\mathrm{p}$ \\
\hline $\mathrm{UCl}$ & 0.5181 & 0.5166 & 0.20 \\
\hline $\mathrm{M} / \mathrm{F}$ & 0.5166 & 0.5153 & \\
\hline $\mathrm{LCl}$ & 0.5151 & 0.5140 & \\
\hline Mean GDP\% & 3.9 & -4.4 & \\
\hline Latvia & 2005-2007 & \multicolumn{2}{|c|}{ 2008-2010 } \\
\hline M & 35019 & 33890 & chi \\
\hline $\mathrm{F}$ & 33689 & 32332 & 0.59 \\
\hline $\mathrm{T}$ & 68708 & 66222 & $\mathrm{p}$ \\
\hline $\mathrm{UCl}$ & 0.5134 & 0.5156 & 0.44 \\
\hline$M / F$ & 0.5097 & 0.5118 & \\
\hline LCl & 0.5059 & 0.5079 & \\
\hline Mean GDP\% & 10.9 & -7.5 & \\
\hline
\end{tabular}

Table 2. M/F for Ireland, 2006-2008

\begin{tabular}{llll}
\hline & $\mathbf{2 0 0 6}$ & $\mathbf{2 0 0 7}$ & $\mathbf{2 0 0 8}$ \\
\hline $\mathrm{M}$ & 33085 & 35574 & 38593 \\
$\mathrm{~F}$ & 31152 & 35046 & 36472 \\
$\mathrm{~T}$ & 64237 & 70620 & 75065 \\
$\mathrm{UCI}$ & 0.5189 & 0.5074 & 0.5177 \\
$\mathrm{M} / \mathrm{F}$ & 0.5150 & 0.5037 & 0.5141 \\
$\mathrm{LCI}$ & 0.5112 & 0.5000 & 0.5105 \\
\hline \multicolumn{4}{c}{ (LCI: Lower Confidence Interval, UCl: Upper } \\
\multicolumn{4}{c}{ Confidence Interval). }
\end{tabular}

The Trivers-Willard hypothesis therefore suggests that under stress, M/F drops. This has been witnessed under different circumstances. For example, the stress engendered by the September 11 attacks on the Twin Towers in the United States in 2001 caused a drop in M/F in New York three months later which rapidly recovered [16]. 


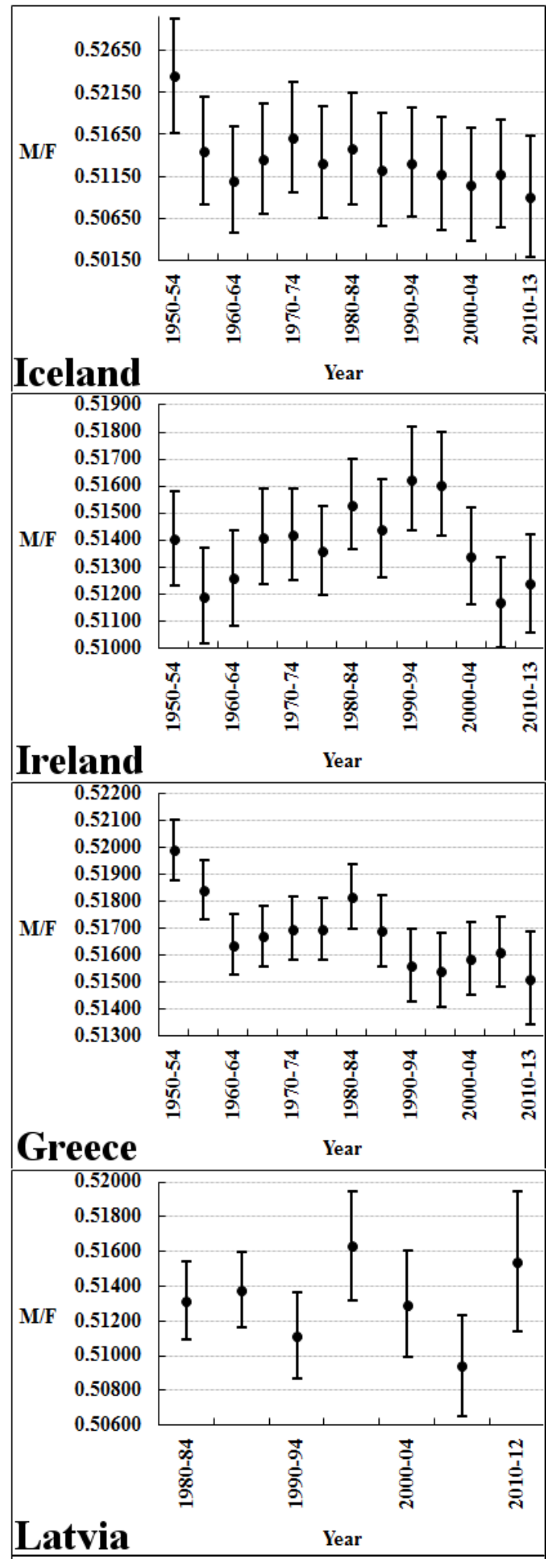

Fig. 1. Five year $M / F$ trends for Iceland, Ireland, Greece and Latvia
Table 3. Quarterly M/F for Ireland, late 2007early 2008

\begin{tabular}{llll}
\hline & 2007Q3 & 2007Q4 & 2008Q1 \\
\hline $\mathrm{M}$ & 9462 & 8515 & 9857 \\
$\mathrm{~F}$ & 9092 & 8951 & 9297 \\
$\mathrm{~T}$ & 18554 & 17466 & 19154 \\
$\mathrm{UCl}$ & 0.5172 & 0.4950 & 0.5217 \\
$\mathrm{M} / \mathrm{F}$ & 0.5100 & 0.4875 & 0.5146 \\
$\mathrm{LCl}$ & 0.5027 & 0.4801 & 0.5075 \\
\hline \multicolumn{4}{c}{ (LCI: Lower Confidence Interval, UCl: Upper } \\
\multicolumn{4}{c}{ Confidence Interval) }
\end{tabular}

The events were also associated with an increase in premature births in the region [17].

These findings have led to the theory that population stress induced by a recession also reduces the human sex ratio. This was shown in East Germany when M/F fell sharply in 1991 after the region's economic collapse following Germany's reunification [4].

Overall, economic depression followed by recession failed to produce any significant longterm effects on $M / F$ in Iceland, Ireland and Greece. The possibility of a type 2 error cannot be excluded due to the relatively small number of births. Alternatively, Ireland may have been harder hit than the other countries and hence only Ireland would have exceeded the threshold for a significant $M / F$ dip. Yet another possibility is that M/F dips in the three other countries may have been short lived but quarterly or monthly data was only available for Ireland.

The onset of the economic downturn had a sharp and non-sustained effect on Irish $\mathrm{M} / \mathrm{F}$ in the last quarter of 2007 to $0.4875(95 \% \mathrm{Cl} 0.4801-$ 0.4950 ) a value well below any in the entire dataset and far below that evidenced in East Germany in 1991 which dipped to 0.522 [4].

Prior to this time, the Irish economy was widely viewed as one of the most successful models worldwide. Economic growth had commenced in the mid-1990s to the early 2000s and was caused by catch-up expansion after years of lagging behind Europe's other economies. Growth was fuelled by favourable demographics which produced an increase not only in number of available workers but also ones with a higher level of education. This instigated a second and more precarious growth phase based on credit expansion and an increase in individual personal indebtedness that caused property prices to soar to unsustainable levels, buoyed by unwise bank lending $[18,19]$. 


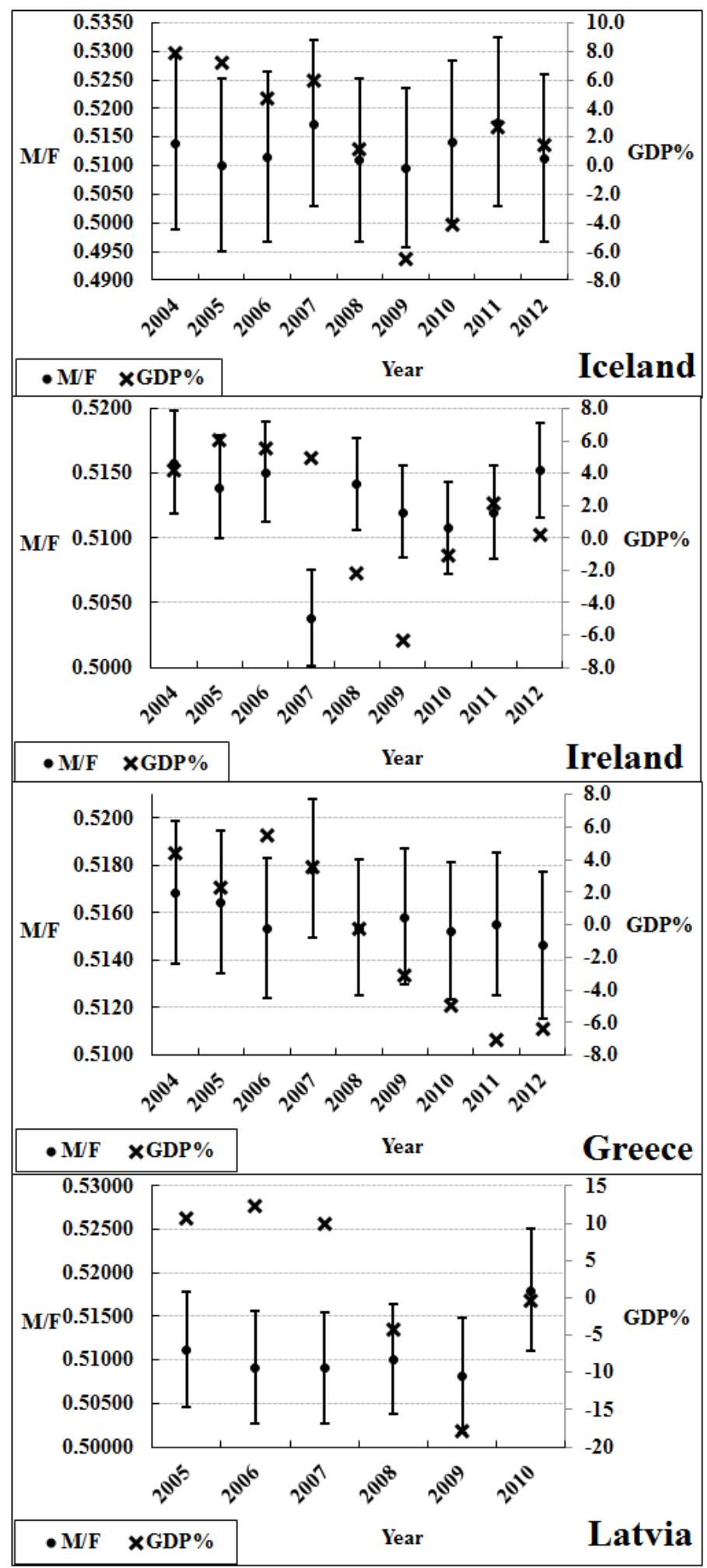

Fig. 2. M/F and GDP\% for periods before and during depression years for Iceland, Ireland, Greece and Latvia 


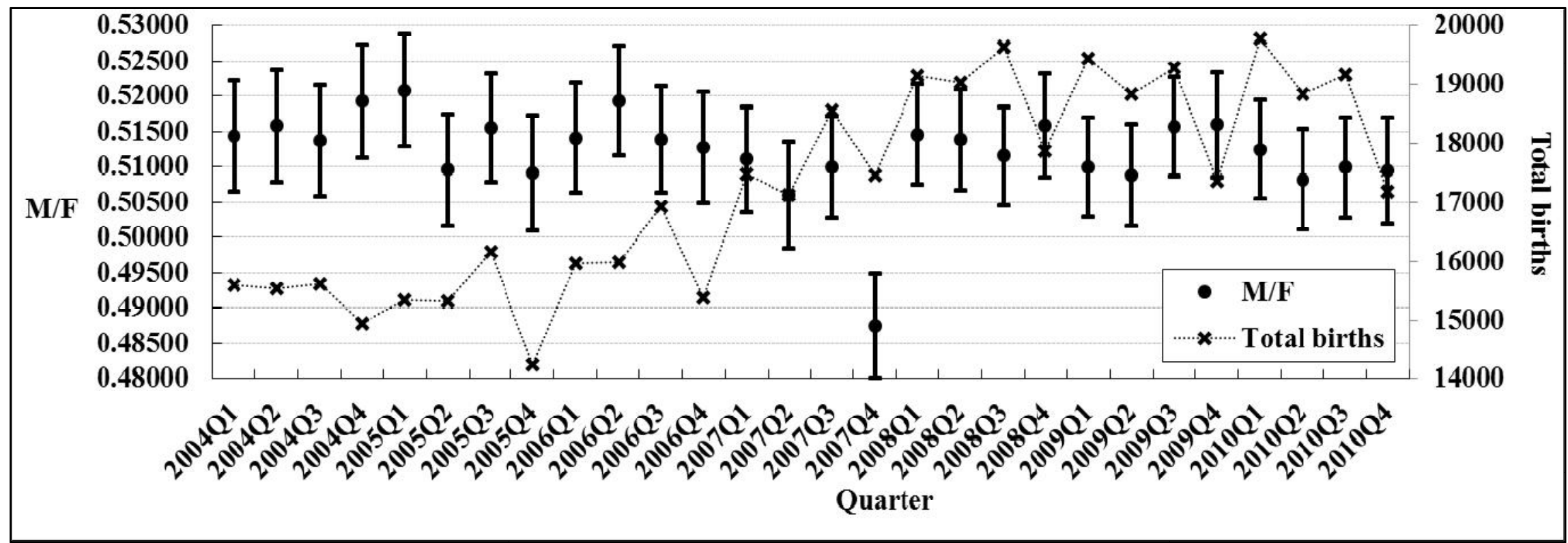

Fig. 3. Quarterly M/F and total births for Ireland, 2004-2010 
The international financial crisis was precipitated on the 9th August 2007 when BNP Paribas, one of the world's largest banks, acknowledged the impact of a looming poor debt crisis by closing two funds. It was at this point that the world's financial services tacitly acknowledged that tens of trillions of dollars of financial derivatives were of dubious security, leading to a seizure in the global banking system [20].

Irish banks were not immune and were highly vulnerable and exposed. Property prices fell and banks took huge losses $[18,19]$. The onset of the crisis was associated with a precipitous yet ephemeral drop in $M / F$ in the fourth quarter of 2007 only. M/F recovered rapidly thereafter and the phenomenon appears similar to that seen in the former East Germany when M/F fell sharply in 1991 following reunification, but recovered by the following year [4].

It is not possible to exclude and much less eliminate other potential triggers that may have influenced $M / F$ and this is an unavoidable limitation in this study.

Stress of any nature appears capable of reducing $\mathrm{M} / \mathrm{F}$. Even relatively mundane events such as democratic parliamentary elections and other similar events may impinge on M/F [21]. The key to identifying such changes is their often transient nature in temporal association to triggering events. Such changes may require inspection of monthly data for identification [21]. However, annual data may also suffice, with changes occurring in just one year followed by a swift recovery. This was also seen, for example, in Cuba, wherein three acts of legislation passed in the United States over the period 1960-96 in order to facilitate the mass emigration of Cuban refugees to the United States from repressive communist rule resulted in three sharp and significant dips in annual $\mathrm{M} / \mathrm{F}$ in the same or the following year (1966, 1980 and 1985) [22].

\section{CONCLUSION}

The Irish data in this study further supports the hypothesis that economic recession reduces $\mathrm{M} / \mathrm{F}$.

\section{CONSENT}

Not applicable.

\section{ETHICAL APPROVAL}

Not applicable.

\section{COMPETING INTERESTS}

Author has declared that no competing interests exist.

\section{REFERENCES}

1. James $\mathrm{WH}$. The human sex ratio. Part 1: $\mathrm{A}$ review of the literature. Hum Biol. 1987;59:721-52.

2. James WH. The human sex ratio. Part 2: $\mathrm{A}$ hypothesis and a program of research. Hum Biol. 1987;59:873-900.

3. Byrne J, Warburton D. Male excess among anatomically normal fetuses in spontaneous abortions. Am J Med Genet. 1987;26:605-611.

4. Catalano RA. Sex ratios in the two Germanies: a test of the economic stress hypothesis. Hum Reprod. 2003;18:1972-5.

5. Krugman P. The Return of Depression Economics. Foreign Affairs. 1999;78:56-74.

6. Boyes R. Meltdown Iceland: Lessons on the World Financial Crisis from a Small Bankrupt Island. New York: Bloomsbury Publishing USA; 2009.

7. Giblin T, Kennedy K, McHugh D. The economic development of Ireland in the twentieth century. New York: Routledge; 2013.

8. Economou M, Madianos M, Peppou LE. Depression and economic hardship across Greece in 2008 and 2009: two crosssectional surveys nationwide. Soc Psychiatry Psychiatr Epidemiol. 2011;46:943-952.

9. Weisbrot M, Ray R. Latvia's recession: The cost of adjustment with an "internal devaluation. Washington: Centre for Economic and Policy Research; 2010.

10. Davis DL, Gottlieb MB, Stampnitzky JR. Reduced ratio of male to female births in several industrial countries: a sentinel health indicator? JAMA. 1998;279:10181023.

11. Slezák P. Microsoft Excel add-in for the statistical analysis of contingency tables. Int J Innovation Educ Res. 2014;2:90-100.

12. Gini C. Sulla probabilita che termini di una serie erratica sieno tutti crescenti (o non decrescenti) ovvero tutti decrescenti (o non crescenti) con applicazioni ai rapporti dei sessi nascite umane in intervalli successivi e alle disposizioni dei sessi nelle fratellanze umane. Metron. 1955;17:1-41. 
13. Fleiss JL. Statistical methods for rates and proportions. 2nd ed. New York: John Wiley. 1981;14-15.

14. Grech V, Vassallo-Agius P, SavonaVentura C. Secular trends in sex ratios at birth in North America and Europe over the second half of the 20th century. J Epidemiol Commun Health. 2003;57:1-4

15. Trivers RL, Willard DE. Natural selection of parental ability to vary the sex ratio of offspring. Science. 1973;179:90-2.

16. Catalano R, Bruckner T, Marks AR, Eskenazi B. Exogenous shocks to the human sex ratio: the case of September 11, 2001 in New York City. Hum Reprod. 2006;21:3127-31.

17. Eskenazi B, Marks AR, Catalano R, Bruckner T, Toniolo PG. Low birthweight in New York City and upstate New York following the events of September $11^{\text {th }}$. Hum Reprod. 2007;22:3013-20.
18. Kelly M. On the likely extent of falls in Irish House Prices. Quarterly Economic Commentary. 2007;42-54.

19. Lane PR. The Irish Crisis. Dublin; Trinity College and CEPR. 2011;356.

20. De Vogli R. The financial crisis, health and health inequities in Europe: the need for regulations, redistribution and social protection. Int J Equity Health. 2014;13:58.

21. Grech V. The male: female ratio at birth is depressed by Maltese parliamentary elections and increased by other nonelectoral events. Int J Trop Dis Health. 2014;4:1123-1131.

22. Grech $V$. The influence of migration on secular trends in sex ratios at birth in Cuba in the past fifty years. West Indian Med J. 2014;4. DOI: 10.7727/wimj.2013.336.

(c) 2015 Grech; This is an Open Access article distributed under the terms of the Creative Commons Attribution License (http://creativecommons.org/licenses/by/4.0), which permits unrestricted use, distribution, and reproduction in any medium, provided the original work is properly cited.

Peer-review history:

The peer review history for this paper can be accessed here: http://www.sciencedomain.org/review-history.php?iid=850\&id=19\&aid=7308 